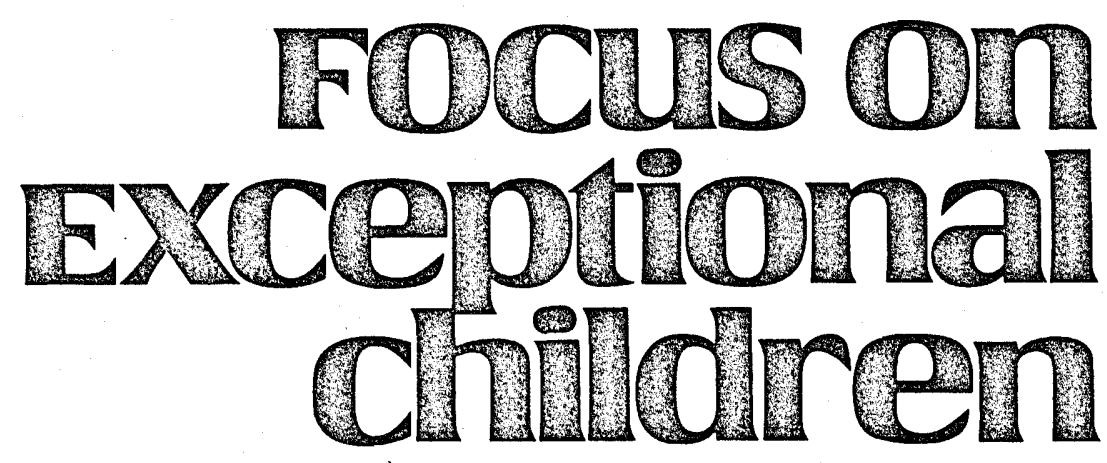

\title{
Preparing Dysfunctional Learners to Enter Junior High School: A Transitional Curriculum
}

\author{
Suzanne M. Robinson, Catherine Trefz Braxdale, and Steven E. Colson
}

Literature in the field of special education continues to reflect the growing movement toward an ecological view of the learner, the environment, and the teacher-resulting in concentrated focus on their interactions (Adelman, 1983; Hardin, 1978; Heron, 1982; Ysseldyke, 1983). Special educators finally are embracing a paradigm that stresses not only the uniqueness of each dysfunctional learner but also that of individual settings. This view proposes that dysfunctional learners often fail because of a mismatch between the learning environment and the learner's present level of functioning. Awareness of students entering a learning environment unprepared has prompted interest in directly facilitating effective transitions to reduce this mismatch (Will, 1985).

Festinger's (1957) view of cognitive dissonance can help educators see the potential for disruption of the teacher-learner match. Environmental demands upon students may disrupt their equilibrium, forcing them to display avoidance behaviors that can lead to a state of dissonance or level of discomfort for learning. Students who experience continual frustration with new settings demands may "shut down," thus preventing any viable flow of questioning and discussion for the purpose of learning.

Most attempts to conceptualize and develop transition curricula have focused on the abrupt and often devastating transition from high school to the world of work (Edgar, 1985; Halpern, 1985 Hasazi, Gordon, \& Roe, 1985; Will, 1985). Armed with limited basic skills, high school seniors with learning handicaps find themselves ill-equipped to function in the workplace. Recently, attempts to expand the concept of transition have included the move from nursery to school. But few educators have explored the need for a curriculum to address the transition from elementary school to junior high school.

We will delineate the differences in school demands between the elementary and junior high settings and address how the transition from the former to the latter could be made smoother for exceptional students through planned instruction. To that end, a proposed transitional program will be discussed. The curriculum to be described is conceptual, drawn from an integration of research on the setting demands of secondary schools, effective intervention, and best instructional practices.

The authors are affiliated with the University of Kansas, where Suzanne Robinson is an Assistant Professor of Special Education, Catherine Braxdale is a Supervisory Teacher, Clinical Classroom for Learning Problems, and Steven Colson is Associate Director of the Clinical Classroom for Learning Problems. 


\section{THE JUNIOR HIGH SCHOOL SETTING}

Students about to enter junior high school often are at a difficult time in their young lives. Most of them are experiencing physical changes and concomitant emotional upheaval. The school environment within which they have learned from kindergarten to the present is about to change. These environmental changes will include a new and bigger school building with greater numbers of students, new content material, a large number of teachers, and increased expectations of independent behavior (Schumaker, Deshler, Alley, \& Warner, 1983). Over the course of 3 summer months, these students lose the status and esteem of having been in the oldest and most knowledgeable group and become the youngest and least respected group.

All of these experiences are magnified for learning disabled (LD) students. Most junior high LD students have a history of receiving special services, and most inevitably have experienced a degree of failure in school (Mercer, 1979). This pattern typically persists. Given the accelerating

\section{FOcus on Exceptional children}

FOCUS ON EXCEPTIONAL CHILDREN (ISSN0015-511X) (USPS 203-360) is published monthly except June, July, and August as a service to teachers, special educators, curriculum specialists, administrators, and those concerned with the special education of exceptional children. This journal is abstracted and indexed in Exceptional Child Education Resources, and is also available in microform from Xerox University Microfilm. Ann Arbor, Michigan. Subscription rates, $\$ 18.00$ per year. Copyright $\odot$ 1985. Love Publishing Company. All rights reserved. Reproduction in whole or part without written permission is prohibited. Printed in the United States of America. Second class postage is paid at Denver, Colorado.

POSTMASTER: Send address changes to:

Love Publishing Company

Executive and Editorial Office

1777 South Bellaire Street

Denver, Colorado 80222

Telephone (303) 757-2579

EDITORIAL BOARD

Edward L. Meyen

University of Kansas

Richard J. Whelan

University of Kansas Medical Center
Stanley F. Love

Publisher
Carolyn Acheson Senior Editor content demands, LD students are faced with new and greatly increased opportunities for failure (Smith, Robinson, \& Voress, 1982).

Changes in existing elementary special education programs might alleviate this situation. Most programs for elementary LD youngsters concentrate on teaching basic skills, but this does not appear enough to prepare LD students for junior high school. Programs might better help these students move into secondary schools by also offering them instruction in compensatory skills, as well as task approach (or learning) strategies that will enable them to master mainstream curriculum demands more independently.

We propose that educators begin to introduce task approach or learning strategy instruction in the upper elementary grades. Research (Schumaker, Deshler, Alley, \& Warner, 1983; Alley, Deshler, Clark, Schumaker, \& Warner, 1983) has demonstrated that secondary-age students profit from learning strategy instruction with a resulting improved performance in mainstream settings. Teacher reports and observation, however, have convinced educators that this type of instruction (teaching students how to learn) must begin earlier than junior high school.

First, students in upper elementary school can learn and profit from knowing independent learning strategies. Second, more secondary-aged LD students would likely be able to be maintained in mainstream settings if they were to have prior knowledge of the learning demands. If the LD student enters the secondary system with no skills with which to compensate for deficits, and thus is unable to function somewhat effectively in mainstream settings, junior and senior high school resource teachers are left with little time and few options. Either they must tutor the student so that a course can be passed or teach basic strategies at the expense of direct tutorial assistance. Neither of these options offers the LD student maximum benefit of time spent with the learning specialist.

If some initial preparation were to take place prior to entering the secondary system, junior high LD teachers could focus immediately on helping students apply learned strategies in mainstream settings, instruct students in more sophisticated learning techniques, and not have to rely solely on tutorial instruction to keep students afloat. Thus, a preventive approach toward future learning problems underlies the proposed curriculum as well as encourages a continuum of learning strategies instruction across elementary and secondary schools.

The following sections address areas in which development of curriculum earlier in the LD student's educational life is needed. Junior high curriculum demands differ from 
those of the elementary school in many areas. These demands/expectations are grouped here as (1) academic, (2) self-management/study skills, and (3) social/adaptive behaviors. The descriptive categories are defined in the following way:

1. Academic demands refer to behaviors associated with successful performance in the classroom for completion of a course with a passing grade or better.

2. Self-management/study skills are behaviors that lead to successful preparation for learning, maximizing reception of actual instruction and appropriate reporting of the material learned in a test situation.

3. Social/adaptive demands are defined here as behaviors that lead to acceptance by peers balanced by respect for authority and the structure of school.

These groupings are made merely for the purpose of explanation. In actuality, the discrete behaviors interact and affect one another. For example, a student who is receiving a failing grade in social studies (academic demand) because that student did not prepare appropriately for the tests (selfmanagement/study skills) may not be allowed to join the football team with all of his friends (social) and possibly acts inappropriately during social studies class as a result of frustration caused by the lack of success (adaptive behavior). Skill deficits in any of these areas impede success.

\section{Academic Demands}

Junior high school teachers assume that their students have acquired at least a minimum level of competency in basic skills prior to entering junior high classrooms. Therefore, the teacher begins instruction using a lecture format, assigning independent reading from the text, presenting further lectures to integrate text material, and then testing over the material covered. Thus, the instructional format changes dramatically from that of elementary school.

The academic subjects presented in content areas (e.g., history, social studies, science, government) all require mastery of basic reading skills. Recent research by several authorities (Johnson, 1977; McClenaghan, 1979; Schumaker \& Beals, 1983; Todd \& Curti, 1982) has indicated that junior high school text readability typically exceeds the grade level at which that text is used. Thus, one of the demands at the junior high school level is reading above grade level or having a proficient strategy for dealing with these accel- erated materials. Armbruster (1984) noted an added burden for students: Many texts are poorly organized and poorly written, warranting the description "inconsiderate text." These demands obviously present serious problems for the typical LD student who is already below grade placement in reading.

Reading also is an integral part of mathematics at the secondary level. No longer is mastery of computation skills the only requirement. Students must read and understand syntactically complex passages (Larsen, Parker, \& Trenholme, 1978). Story problems, presentation of concepts, directions for working sample problems, and explanations of examples must be assimilated to perform nightly homework assignments.

In addition to substantial reading demands in all content areas, proficiency in writing is necessary for academic success. Skills in handwriting, spelling, punctuation, and sentence structure are integrated and generalized to tasks such as creative writing, book reports, thematic and term papers, and testing (Smith, Robinson, \& Voress, 1982). LD students have extreme difficulty with written production, compounded by a lack of skill in detecting errors in their work. Without the ability to proofread or monitor errors, they have little chance of improving a poor product (Deshler, Ferrell, \& Kass, 1978).

\section{Self-Management Demands/Study Skills}

The junior high setting demands more independence and self-control than does the elementary school (Nesselroade \& Reese, 1973). Students are expected to have developed study habits, to be able to complete assignments without reminders, and to request assistance when it is needed (Schumaker, Deshler, Alley, \& Warner, 1983). Albeit difficult, after only a few weeks or even months normally achieving students begin to develop a system for notetaking, recording assignments, completing homework in a timely manner, and preparing for tests. These new demands all emphasize skills in which most LD and underachieving students are deficient (Link, 1980; Mercer, 1979; Schumaker et al., 1983).

The demand for more independent learning behavior is further evidenced by the instructional format of junior high school classrooms. Lecture is the predominant teaching style, and students have few opportunities during class to provide the teacher with feedback pertaining to degree of understanding (Moran, 1980). Tests or written products constitute the predominant means of student evaluation 
(Schumaker et al., 1983). Smith, Robinson, and Voress (1982), however, noted that most junior high-age LD students were deficient in comprehending, evaluating, and acting on oral information, as well as evidencing difficulty in self-questioning, self-monitoring, or self-testing behaviors. These students undoubtedly will have difficulty functioning well in the junior high setting.

\section{Social/Adaptive Demands}

LD adolescents surely must find junior high school frustrating. Their approach to learning is largely unsuccessful. Their deficiencies in reading directly affect academic success. These problems are compounded by social or interaction demands for which they are unprepared. Following classroom rules presents a particular problem for $L D$ adolescents. Many LD youngsters are handicapped by poor social perceptions, visual and auditory misinterpretations of social cues, gestures, affective states, and verbal messages (Bryan, 1978; Cook, 1979; Kronick, 1978).

As the spoken and written requirements for success in each classroom vary with each teacher, students must try to adjust behavior to meet the demand. Brown (1982) explained that one environment may require a great amount of verbal exchange (language experience or group discussion) and another may require silence (study hall). Thus, the need for interactive learning skills (understanding nonverbal cues of behavioral expectations, responding appropriately to feedback, asking for clarification, participating effectively in group discussions, etc.) becomes evident.

The transition from elementary school to junior high school is difficult for most LD students. Students struggling to meet the academic demands of sixth grade in May probably will not be able to cope with the academic, self-management, and social demands of the junior high setting in September. If special education programs at the elementary level would direct some attention to the compensatory skills and learning strategies discussed here, LD students would be better prepared for the accelerating demands of the secondary setting.

\section{THE TRANSITION CURRICULUM- WHAT TO TEACH}

The elementary school LD teacher typically has a multitude of goals that guide instruction for each LD student served. Therefore, a program designed to facilitate students' transitions from elementary to middle school settings must be limited (there already is much to teach within the elementary program), yet it must target skills most problematic to LD youngsters upon entry into junior high school.

Skills selected for the transitional curriculum should be those not typically taught in elementary school, yet necessary for success in junior high settings. Therefore, both preparing for success in junior high school and acknowledging the existent demands of the elementary setting guided (as well as limited) skill selection for the proposed curriculum. Mehl (1984) surveyed junior high school teachers about skills in which LD students were least prepared and caused them most difficulty upon entering junior high settings. From this study and a review of the literature, the following skill list was developed to serve as the core of the transition curriculum. It is not assumed to be a list of all skills necessary for success in junior high school. Instead, it identifies critical areas that cause significant problems for a predominant number of LD youngsters. Other skills not included in the core curriculum but which might be of particular concern in regard to specific students could be added. Table 1 delineates each skill under the categories of academic skills, self-management/study skills, and social/adaptive behavior. A final category, general orientation to junior high, also is discussed briefly.

\section{Academic Skills Featured in the Transition Curriculum}

As noted earlier, reading often ceases to be a subject in and of itself in junior high schools. Rather, it becomes a tool by which content material is assimilated. Therefore, LD students must become proficient at extracting meaning from difficult-to-read material if they are to succeed in mainstream junior high settings. Comprehending content material, then, becomes an important instructional goal.

Research in reading (Capelli \& Markman, 1982; Markman, 1981) demonstrated that a skill crucial to understanding and remembering text is the ability to accurately summarize information in one's own words. This cognitive process facilitates the integration of information through continual review of what was read. Furthermore, researchers (Brown \& Palincsar, 1982; Capelli \& Markman, 1982; Wong \& Jones, 1982) successfully taught LD youngsters both at the elementary and junior high school levels to monitor their reading comprehension in this manner. Thus, the transitional curriculum would include teaching students to paraphrase the main idea and selected details of paragraphs and longer reading selections (Schumaker, Denton, \& Deshler, 1984). 


\section{TABLE 1}

\section{Skills Taught in the Transition Curriculum}

\section{SKILL}

\section{Academic Skills}

1. Reading for the purpose of content comprehension (Deemphasis on decoding)

1.1 Paraphrasing/Summarizing

1.1.1 Oral paraphrasing

1.1.2 Written paraphrasing/ Taking notes from text

1.2 Text analysis

\section{Self-Management/Study Skills}

2. Listening

2.1 Following oral directions

2.2 Notetaking from lectures

3. Self-Management

3.1 Planning Work Time

3.1.1 Planning time use at school

5th 6th

Grade Grade

3.1.2 Planning study time at home

3.1.3 Organization of materials

3.2 Record-Keeping Techniques

3.2.1 Assignment record keeping

3.2.2 Assignment completion

3.2.3 Self-evaluation of assignments before submission

4. Test Taking

4.1 Test preparation

4.2 Test taking

\section{Social/Adaptive Behavior}

5. Interactive Learning

5.1 Appropriate questioning

5.2 Interpreting feedback

5.3 Group discussion skills

\section{$x$}

$x$
The ability to paraphrase and summarize information also is important in notetaking (Saski, Swicegood, \& Carter, 1983). Since taking notes from texts and lectures is a significant new demand of the junior high school setting, students would be taught to apply the skill of paraphrasing main ideas and key details to taking notes.

Knowledge about textbook organization is another skill not typically taught in the elementary school years, but it is extremely helpful in gaining information from texts. The ability to identify how a chapter fits into a book section, how boldface print and italics indicate main ideas, key details, and important vocabulary, and how illustrations are used to reinforce and restate important information can help LD youngsters better comprehend information in textbooks (Larkin \& Reif, 1976; Alley \& Deshler, 1979). Therefore, youngsters in the transitional curriculum would learn basic skills of text analysis.

\section{Self-Management/Study Skills}

\section{Listening and Notetaking}

Students at the junior high school level must be able to listen well. More class time is spent listening to lectures than was the case in elementary school (Moran, 1980), and students must be able to follow oral directions given by six or seven different teachers each day. Yet, students receive little instruction in how to listen well (Robinson \& Smith, 1981).

Therefore, a component of the transitional curriculum would be instruction in strategies students could use to remember and follow oral directions and to listen to lectures and take notes. Robinson (1983) demonstrated that upper elementary LD students could successfully apply a rehearsal strategy to the task of following oral directions after a minimum amount of instruction. Another researcher (Seager, 1985) found that LD students could learn to identify important information in lectures and note it in a manner that could be deciphered and studied later, thereby increasing their comprehension of lecture material as measured by delayed comprehension tests. Both skills are critical to success in the junior and senior high school settings and, in both, LD teachers perceive students to be woefully inadequate (Mehl, 1984).

\section{Self-Management}

LD students find the increasing demand to work independently a source of great difficulty. No longer are one or two 
solicitous teachers on hand to help students complete work over the course of a day or a week. Instead, LD youngsters are faced with the differing demands of six or seven teachers whose ability to assist students in completing work is limited by the short time in which teacher and student are in contact and by the fact that each teacher is attempting to meet the demands of 150 or so students each day. Indeed, independent work skills are necessary for success in junior high schools.

Self-management requires students to become actively involved in managing their own educational programs. Research (Dickerson \& Creedon, 1981; Seabaugh \& Schumaker, 1981; Smith, 1984) has demonstrated that when instructional methods require the learners' active participation in planning the use of their time, most students increase their independent work and seem to change their motivational levels, thereby doing and learning more. Planning one's own work time has been taught successfuly to elementary-aged LD students, with a resulting increase in productivity (Lovitt, 1973).

Getting the work done is not enough, though. Work usually is evaluated on the basis of quality. Therefore, it is recommended that students also be taught self-evaluation procedures. Researchers (Hallahan, Marshall, \& Lloyd, 1981; Kneedler \& Hallahan, 1981; Lloyd, Hallahan, Kosiewicz, \& Kneedler, 1982; Schumaker, Deshler, Nolan, Clark, Alley, \& Warner, 1981) found that self-recording of performance quality on an evaluative checklist (e.g., Did I do what I supposed to do? Did I find all the punctuation errors? etc.) produced positive performance changes. The ability to evaluate the quality of one's work prior to submission to a teacher should increase a student's success in independent learning situations. Thus, time management, assignment completion, and self-evaluation would be included in the transitional curriculum.

\section{Test Taking}

Another study skill that gains in importance during junior high school is test taking. Knowledge of course content often is measured through one's performance on tests. Yet, elementary students often have minimal experience with the objective or essay test formats commonly used in junior and senior high settings. Knowledge about study techniques, terminology used on tests, test preview procedures, scheduling time for completion and review, use of clue words, and how to estimate or "guess" on difficult questions can help LD students perform better in evaluation situations. Therefore, test preparation techniques, as well as strategies to use while taking a test, would be included in the study skills section of the curriculum.

\section{Social/Adaptive Behaviors}

Learning in an interactive manner (talking with others in a class discussion, asking questions, receiving feedback from teachers and peers) is important in both elementary and junior high school settings. Teachers' perceptions change, however, as students progress into higher grades; teachers believe that their students are fairly proficient in these interactive learning behaviors by the time they reach junior high school. Yet, the social deficiencies of the LD adolescent are well documented (Hazel, Schumaker, \& Sheldon-Wildgen, 1981; Schumaker et al., 1983). Specifically, the teachers surveyed by Mehl (1984) noted class discussion skills, the ability to ask appropriate questions, and accepting feedback as areas in which LD youngsters entering junior high school were deficient and in need of instruction.

\section{Orientation to Junior High School}

Parents and teachers report that the specter of junior high creates anxiety for most students. Therefore, a thorough orientation to the junior high setting, informing incoming students of what they will encounter, is necessary. This often is a component of the last semester of elementary school for all students.

Successful components of an orientation process include counselors from the junior high school visiting the elementary students to talk about courses, requirements, and scheduling; going on a tour of the new school; and holding orientation meetings for parents and new students (Bent, 1976; Allan \& McKean, 1984). However thorough this orientation process might be, the likelihood that LD youngsters will need more information is great. Junior high school demands (moving from class to class within a time limit, organizing and retrieving needed materials from lockers, working a combination lock, coping with more than one teaching style, following a schedule, and so forth) require explicit clarification and discussion for students with learning disabilities. Possible repeat visits from junior high school counselors to answer new questions that students might have after thinking and talking about the junior high setting would aid this process. Providing explicit information about the new and upcoming environmental changes has the potential of circumventing considerable confusion for $\mathrm{LD}$ youngsters (Allan \& McKean, 1984; Quattropani, 1982). 
A curriculum designed to ease the transition from elementary to junior high school must meet two goals:

1. It must be effective, including skills most crucial to success in the new school setting.

2. It must be efficient.

The needs of LD youngsters at the end of elementary school often are many, and certainly varied. Basic skill instruction must continue. Thus, a transitional curriculum must be limited in both scope and necessary time to implement. The proposed curriculum was designed to meet both goals.

\section{A TRANSITION CURRICULUM-HOW TO TEACH}

Intervention success can be attributed to a constellation of variables that has been orchestrated well. For example, skills necessary for school success have been identified, student need for each skill has been validated, development of prerequisite skills has occurred, and teachers have adhered to effective teaching practices. In other words, a combination of knowing what to teach and how to teach will increase the likelihood of successful instruction.

Assessment of the learner's present level of performance is crucial in choosing what skills to teach. Equally important is to limit instruction to only those skills that appear deficient after a preliminary assessment. Observing and interviewing both teacher and student can provide invaluable information in compiling a list of deficit areas in need of remediation.

We suggest that a checklist similar to that of Figure 1 be used before placing any student in a transition curriculum. Furthermore, it is advantageous to delineate specifically at what level of understanding each skill has been integrated into the student's daily performance. In evaluating a student's skill usage, checking either "yes" or "no" gives little insight into the learner's readiness to learn that or any skill. An instructional hierarchy both for assessing the student's present level of performance and to what extent each skill is needed for a particular grade or course is recommended. Checking "no knowledge of this skill" would indicate a more intensive approach to remediating this deficit. "Skill emerging - teacher assistance required" would warrant an instructional approach that can build on the student's existing knowledge in this area. Indicating that a student has "mastery of this skill/can train other students" would require only minimal spot-checks by the teacher while also denoting a possible peer tutor for other students in the curriculum.
The teacher effectiveness literature has confirmed the utility of specific teaching practices to ensure student achievement (Bloom, 1984; Englert, 1984; Rosenshine, 1983). Providing structure and systematic instruction, using modeling and guided practice, maximizing time in which students are actively engaged in learning activity, and applying mastery learning principles are all techniques that researchers have proved to be highly effective.

Deshler and his colleagues (Deshler, Alley, Warner, \& Schumaker, 1981; Schumaker, Deshler, Alley, \& Warner, 1983) developed and validated, through numerous replications, a sequence of instructional steps that incorporates the previously mentioned effective teaching tactics to promote the acquisition of new learning behaviors. Others (Hazel, Schumaker, \& Sheldon-Wildgen, 1981; Robinson, 1982; Seager, 1985) also have found these instructional steps effective in teaching LD youngsters listening skills, notetaking, comprehension techniques, and other academic and social skills. For the purpose of this discussion and the subsequent example lesson plan, the eight-step instructional sequence developed by Deshler et al. (1981) will be used. In this instructional sequence:

Step 1 consists of evaluation of a student's current learning style. If inefficient or ineffective, the need for a new approach to the task is confirmed and discussed with the student.

Step 2 involves describing the new strategy or method of approaching the task.

Step 3 consists of the teacher's modeling the new learning behavior, which may include "thinking aloud" while doing the task.

Step 4 requires the student to rehearse verbally what he or she is to do, ensuring that the student knows what to do and can self-instruct at a later point.

Step 5 requires the student to practice the skill in controlled materials (e.g., ability level reading material, a role play situation) so that mastery of the new learning behavior is assured before asking the student to apply it to a "real" demand (for example, taking notes in a regular classroom lecture, reading a grade level text, taking a final exam in geography class).

Step 6 consists of student practice in grade-appropriate materials.

Step 7 is a posttest and discussion of the need to generalize newly learned skills to other settings.

Step 8 consists of tactics to assure generalization through review of the new learning behavior, discussion 


\section{FIGURE 1}

\section{Pre-Assessment of the Learner}

Student:

Grade:

Date:

Teacher:

Subject:

SCORING: (1) No knowledge of this skill

(2) Awareness only of this skill
(3) Skill emerging-teacher assistance required

(4) Semi-independence for this skill-teacher assistance rarely needed

(5) Mastery of this skill/can train other students

\begin{tabular}{|c|c|c|c|}
\hline Student can: & $\begin{array}{c}\text { Student's present } \\
\text { level }\end{array}$ & $\begin{array}{l}\text { Level of skill needed } \\
\text { for this grade/course }\end{array}$ & Comments \\
\hline \multicolumn{4}{|l|}{$\begin{array}{l}\text { LSTENING } \\
\text { - Follow multiple-step oral directions }\end{array}$} \\
\hline \multicolumn{4}{|l|}{ - Take appropriate, readable notes from lectures } \\
\hline \multicolumn{4}{|l|}{$\begin{array}{l}\text { SELF-MANAGEMENT } \\
\text { - Plan timeneeded for reading assignments }\end{array}$} \\
\hline \multicolumn{4}{|l|}{ - Plan time needed for written assignments } \\
\hline \multicolumn{4}{|l|}{ - Bring appropriate materials to class } \\
\hline \multicolumn{4}{|l|}{ - Attend class regularly } \\
\hline \multicolumn{4}{|l|}{ - Arrive to class promptly } \\
\hline \multicolumn{4}{|l|}{$\begin{array}{l}\text { RECORD KEEPING } \\
\text { - Keep records of assignments due } \\
\end{array}$} \\
\hline \multicolumn{4}{|l|}{ - Complete assignments on time } \\
\hline \multicolumn{4}{|l|}{ - Self-evaluate potential grade of assignments/tests } \\
\hline \multicolumn{4}{|l|}{$\begin{array}{l}\text { READING CONTENT FOR COMPREHENSION } \\
\text { - Paraphrase in written form }\end{array}$} \\
\hline \multicolumn{4}{|l|}{ - Paraphrase orally } \\
\hline \multicolumn{4}{|l|}{ - Take accurate and appropriate notes from texts } \\
\hline \multicolumn{4}{|l|}{ - Read/interpret graphs } \\
\hline \multicolumn{4}{|l|}{ - Read/interpret illustrations } \\
\hline \multirow{2}{*}{\multicolumn{4}{|c|}{ - Take advantage of boldfaced/italicized words }} \\
\hline \multicolumn{3}{|l|}{ - Take advantage of chapter prefaces/summaries } & \\
\hline \multicolumn{4}{|l|}{ - Use a table of contents } \\
\hline - Use aglossary & & & \\
\hline \multicolumn{4}{|l|}{ - Interpret maps } \\
\hline \multicolumn{4}{|l|}{$\begin{array}{l}\text { TESTTAKING } \\
\text { - Prepare fortests } \\
\end{array}$} \\
\hline \multicolumn{4}{|l|}{ - Succeed on true/false tests } \\
\hline \multicolumn{4}{|l|}{ - Succeed on multiple-choice tests } \\
\hline \multirow{2}{*}{\multicolumn{4}{|c|}{$\begin{array}{l}\text { - Succeed on matching tests } \\
\text { - Succeed on essay tests }\end{array}$}} \\
\hline & & \multicolumn{2}{|c|}{ - Succeed on essay tests } \\
\hline \multicolumn{4}{|l|}{$\begin{array}{l}\text { INTERACTIVE LEARNING } \\
\text { - Ask appropriate questions }\end{array}$} \\
\hline \multicolumn{4}{|l|}{$\begin{array}{l}\text { - Ask for teacher assistance for assignment clarification } \\
\text { /additional information in an appropriate manner } \\
\end{array}$} \\
\hline \multicolumn{4}{|l|}{ - Accept criticism/praise } \\
\hline $\begin{array}{l}\text { - Participate in class discussions using complete } \\
\text { thoughts, staying on current topic with } \\
\text { appropriate comments/questions }\end{array}$ & & & \\
\hline
\end{tabular}


of where it best can be applied, and supervised practice of the new technique in the generalization settings.

Concurrent with all steps is the use of specific corrective feedback to inform students how they are doing and what they must do to master the task. (Please refer to Deshler, Alley, Warner, \& Schumaker, 1981, or Schumaker, Deshler, Alley, \& Warner, 1983, for further discussion of this instructional procedure). Figure 2 is an example lesson plan for the way in which the time management skill of record keeping might be taught.

\section{FIGURE 2}

\section{Lesson Plan for Instruction in Record Keeping}

Skill: Self-Management

Subskill: Record-Keeping Techniques

Component Skill: Assignment Record Keeping

Daily Time Requirements: 5 minutes in the resource room. This unit is supplemental to any selected area of study. These presentations can be made in tandem with other assignments in the resource room.

\section{Day 1}

Objective:

- Initiate acquisition of Assignment Record-Keeping Strategy.

\section{Step \#1 \\ Analysis of Current Learning Habit}

\section{Procedure:}

- Discuss how the student is currently recording assignments in the regular classroom.

- Discuss how knowing what was assigned is the first step in correctly completing homework.

- Ask whether the student's current strategy for recording assignments is working.

- Ask the student how accurate recording of assignments could help his or her grades.

\section{Day 2}

Objective:

- Initiate acquisition of Assignment Record-Keeping Strategy.

Procedure:

- Assist the student in identifying subject area(s) in which assignment recording is crucial.

- Discuss all subjects that require homework.

- Explore with student the subject in which he or she has the lowest grade or in which he or she has the most trouble.

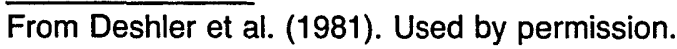

\section{Day 3}

Objective:

- Assist the student in developing a form for recording assignments.

\section{Step \#2}

Describe the New Strategy

\section{Procedure:}

- Assist the student through discussion in identifying what information should be recorded in order to correctly complete an assignment.

- Discuss how the student could keep this chart available for easy access.

- Assist the student in making the chart simple to maintain.

\section{Example:}

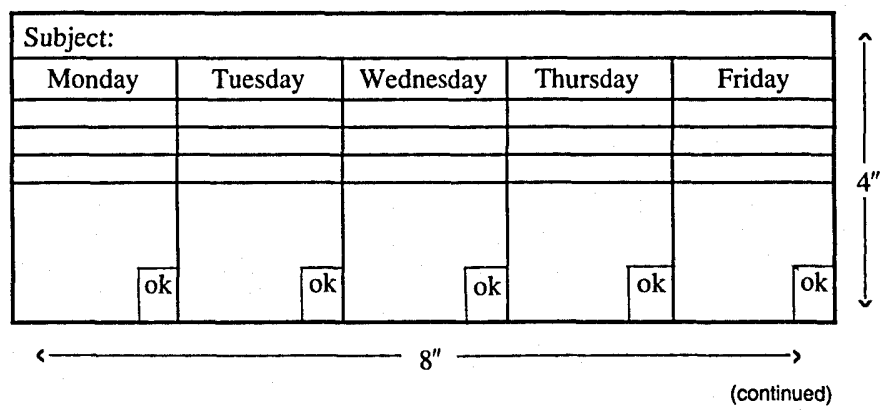


(Figure 2, cont.)

\section{Day 4}

Objective:

- Initiate use of the chart.

\section{Step \#3}

Model the New Strategy

Procedure:

- Provide practice for the use of the chart. Using two examples, copy an assignment from the board and write it down as teacher gives it orally.

- Role play with the student. Act as the student checking with the regular classroom teacher to clarify the assignment.

- Role play with the student. Have the student give an assignment and the teacher copy it.

\section{Step \#4}

Verbal Rehearsal of the Strategy's Steps

\section{Procedure:}

- Provide practice situation wherein the student will verbalize all the steps required for correctly recording the assignment..

a. Chart (or paper) is available.

b. Pencil (or pen) is available.

c. Correct date is written.

d. Correct subject name is written.

e. Page numbers are written.

f. Type of assignment (read, write, answer, etc.) is noted.

g. Date due is included.

\section{Day 5}

\section{Objective:}

- Continue verbal rehearsal of the strategy, and provide practice for its use.

\section{Procedure:}

- Provide practice in developing a chart for keeping track of all assignments correctly recorded.

- Discuss with the student when he or she will mark this chart during the time in the resource room.

- Agree upon a student-selected reward for 5 correct recordings of assignments.
Example:

\begin{tabular}{|l|l|l|l|l|l|}
\hline$\# 1$ & $\# 2$ & $\# 3$ & $\# 4$ & $\# 5$ & Reward \\
\hline & & & & & popcorn \\
\hline & & & & & \\
\hline & & & & & \\
\hline
\end{tabular}

\section{Days 6 through 10}

\section{Objective:}

- Provide a controlled situation in which the student can practice the new strategy.

\section{Step \#5}

Student Practices in Controlled Situation

\section{Procedure:}

- Throughout the week give assignments as usual. Provide feedback to the student, through use of the student-developed check chart, as to whether the student has correctly recorded the assignment.

- Provide corrective feedback to the student if the student has not correctly recorded the assignment.

\section{Day 11 through 15}

Objective:

- Provide the student with the opportunity to use the assignment chart in a selected regular classroom.

\section{Steps \#6-8}

\section{Student Practices in Grade-Appropriate} Practice and Generalization

\section{Procedure:}

- Through interview, discuss again what subject requires the most homework. Review how the strategy can be used in that setting.

- Practice record keeping in mainstream setting with regular corrective feedback.

- Continue to chart correct recordings of homework assignments in the resource room, with subsequent rewards.

- Continue maintenance check after mastery is reached. 
The transitional curriculum described here was conceptualized with an awareness of pre-existing instructional obligations. Obviously, many students have learning deficits that require immediate attention and remedial instruction. Therefore, the skills included in the curriculum would be taught over a 2-year period. Skill introduction in fifth or sixth grade is suggested (and noted in Table 1) with possible utilization in existing elementary settings in mind. Individual settings and student needs, however, must determine the actual skills sequence for a given student.

\section{CONCLUSION}

Broadening the existing concept of transition and transition curricula can help narrow the cognitive dissonance between dysfunctional learners and the junior high school. With a growing body of research supporting a learning strategies curriculum (Alley, Deshler, Clark, Schumaker, \& Warner, 1983; Deshler, Schumaker, Alley, Warner, \& Clark, 1982; Robinson, 1983; Schumaker, Deshler, Alley, \& Wamer, 1983; Seager, 1985), special education now must focus on the efficacy of adapting strategic learning instruction for dysfunctional learners entering the junior high school setting. Waiting until the student has entered the junior high setting before initiating transitional efforts can only prolong the period of cognitive dissonance, resulting in a losing game of catch-up. Adopting an effective curriculum that prepares dysfunctional students before entry into the junior high school setting can facilitate smooth educational transitions from elementary school to the accelerating demands of secondary programs.

\section{REFERENCES}

Adelman, H. (1983). Learning disabilities in perspective. Glenview, IL: Scott, Foresman.

Allan, J., \& McKean, J. (1984). Transition to junior high school: Strategies for change. School Counselor, 5, 43-48.

Alley, G., \& Deshler, D. (1979). Teaching the learning disabled adolescent: Strategies and methods. Denver, CO: Love Publishing.

Alley, G., Deshler, D., Clark, F., Schumaker, J., \& Warner, M. (1983). Learning disabilities in adolescents and young adult population: Research implications (Part II). Focus on Exceptional Children, 15(1), $1-16$.

Armbruster, B.B. (1964). The problem of "inconsiderate text." In G. Duffy, L. Roehler, \& J. Mason (Eds.), Comprehension instruction: Perspectives and suggestions. New York: Longman.

Bent, A. (1976). Orientation and the transfer student. Clearing House, $49,350-352$.

Bloom, B.B. (1984). The search for methods of group instruction as effective as one-to-one tutoring. Educational Leadership, 41, 4-17.
Brown, A.L., \& Palincsar, A.S. (1962). Inducing strategic learning from texts by means of informed, self-control training. Topics in Learning \& Learning Disabilities, 2, 1-17.

Brown, L. (1982). Evaluating and managing classroom behavior. In D.D. Hammill \& N.R. Bartel (Eds.), Teaching children with learning and behavior problems (3rd ed.). Boston: Allyn \& Bacon.

Bryan, T.H. (1978). Social relationships and verbal interactions of learning disabled children. Journal of Learning Disabilities, 11, 107-115.

Capelli, C.A., \& Markman, E.M. (1962). Suggestions for training comprehension monitoring. Topics in Learning \& Learning Disabilities, 2, 89-96.

Cook, L.D. (1979). The adolescent with a learning disability: A developmental perspective. Adolescence, 14, 697-707.

Deshler, D.D., Alley, G., Warner, M., \& Schumaker, J.B. (1981). Instructional practices for promoting skill acquisition and generalization in severely learning disabled adolescents, Learning Disability Quarterly, 4, 415-421.

Deshler, D.D., Ferrell, W.K., \& Kass, C.E. (1978). Error monitoring of schoolwork by learning disabled adolescents. Journal of Learning Disabilities, 11, 401-414.

Deshler, D.D., Schumaker, J., Alley, G., Warner, M., \& Clark, F. (1982). Learning disabilities in adolescents and young adult population: Research implications (part 1). Forus on Exceptional Children, 15(9), $1-12$.

Dickerson, E.H., \& Creedon, C.F. (1981). Self-selection of standards by children: The relative effectiveness of pupil-selected and teacherselected standards of performance. Journal of Applied Behavior Analysis, 14, 425-433.

Edgar, E. (1985). How do special education students fare after they leave school? A response to Hasazi, Gordon, and Roe. Exceptional Children, $51(6), 470-473$.

Englert, C.S. (1984). Effective direct instruction practices in special education settings. RASE, 5, 38-47.

Festinger, L.A. (1957): A theory of cognitive dissonance. Stanford, CA: Stanford University Press.

Hallahan, D.P., Marshall, K.J., \& Lloyd, J.W. (1981). Self-recording during group instruction: Effects on attention to task. Learning Disability Quarterly, 4, 407-413.

Halpern, A. (1985). Transition: A look at the foundations. Exceptional Children, 51(6), 479-486.

Hardin, V. (1978). Ecological assessment and intervention for learning disabled students. Learning Disability Quarterly, 1, 15-20.

Hasazi, S., Gordon, L., \& Roe, C. (1985). Factors associated with the employment status of handicapped youth exiting high school from 1975 to 1983. Exceptional Children, 51, 455-469.

Hazel, J.S., Schumaker, J.B., \& Sheldon-Wildgen, J. (1981). Application of a social skill and problem-solving group training program to learning disabled and non-learning disabled youth (Research report \#30). Lawrence, KS: University of Kansas Institute for Research in Learning Disabilities.

Heron, T., \& Heward, W. (1982). Ecological assessment: Implications for teachers of learning disabled students. Learning Disability Quarterly, 5, 117-125.

Johnson, R.E. (1977). The reading level of elementary social studies textbooks is going down. Reading Teacher, 30, 901-906.

Kneedler, R.D., \& Hallahan, D.P. (1981). Self-monitoring of on-task behavior with learning disabled children: Current studies and directions. Exceptional Education Quarterly, 2, 73-82.

Kronick, D. (1978). An examination of psychosocial aspects of learning disabled adolescents. Learning Disability Quarterly, 1, 86-93.

Larkin, J.H., \& Reif, F. (1976). Analysis and teaching of a general skill for studying a scientific text. Journal of Educational Psychology, 68, 431-440. 
Larsen, S.C., Parker, R.M., \& Trenholme, B. (1978). The effects of syntactic complexity upon arithmetic performance. Learning Disability Quarterly, 1, 80-85.

Link, D.P. (1980). Essential learning skills and the low achieving student at the secondary level: $A$ rating of the importance of 24 academic abilities. Unpublished master's thesis, University of Kansas, Lawrence.

Lloyd, J.W., Hallahan, D.P., Kosiewicz, M.M., \& Kneedler, R.D. (1982). Reactive effects of self-assessment and self-recording on attention to task and academic productivity. Learning Disability Quarterly, 5, 216227.

Lovitt, T.C. (1973). Self-management projects with children with learning disabilities. Journal of Learning Disabilities, 6, 138-150.

Markman, E.M. (1981). Comprehension monitoring. In W.P. Dickson (Ed.), Children's oral communication skills. New York: Academic Press.

McClenaghan, W.A. (1979). Magruder's American government. Boston: Allyn \& Bacon.

Mehl, K.A. (1984). Teachers' perceptions of student preparedness and the skills necessary for success in the junior high classroom. Unpublished master's thesis, University of Kansas, Lawrence.

Mercer, C.D. (1979). Children and adolescents with learning disabilities. Columbus, $\mathrm{OH}$ : Charles E. Merrill.'

Moran, M.R. (1980). An investigation of the demands on oral language skills of learning disabled students in secondary classrooms (Research report \#1). Lawrence: University of Kansas Institute for Research in Learning Disabilities.

Nesselroade, J.R., \& Reese, H.W. (1973). Life span development psychology: Methodological issues. New York: Academic Press.

Quattropani, D.J. (1982). Smoothing the transition to secondary school. Principal, 61, 55.

Robinson, S.M. (1983). A study of the efficacy of instruction in two strategies, rehearsal and self-questioning, to increase listening skills of learning disabled students. Unpublished doctoral dissertation, University of New Mexico, Albuquerque.

Robinson, S.M., \& Smith, D.D. (1981). Listening skills: Teaching learning disabled students to be better listeners. Focus on Exceptional Children, 13(8), 1-15.

Rosenshine, B. (1983). Teaching functions in instructional programs. Elementary School Journal, 83, 335-351.
Saski, J., Swicegood, P., \& Carter, J. (1983). Notetaking format for learning disabled adolescents. Journal of Learning Disabilities, 6, $265-$ 272.

Sattler, J.M. (1982). Assessment of children's intelligence and special abilities. Boston: Allyn \& Bacon.

Schumaker, J.B., \& Beals, V. (1983). An analysis of readability of commonly used textbooks at the secondary level (Research monograph). Lawrence: University of Kansas Institute for Research in Learning Disabilities.

Schumaker, J.B., Denton, P.H., \& Deshler, D.D. (1984). The paraphrasing strategy. Lawrence, KS: University of Kansas.

Schumaker, J.B., Deshler, D.D., Alley, G.R., \& Warner, M.W. (1983). Toward the development of an intervention model for learning disabled adolescents: The University of Kansas. Exceptional Education Quarterly, 4, 45-74.

Schumaker, J.B., Deshler, D.D., Nolan, S., Clark, F.C., Alley, G.R., \& Warner, M.M. (1981) (Research report \#32). Error monitoring: A learning strategy for improving academic performance of $L D$ adolescents. Lawrence: University of Kansas Institute for Research in Learning Disabilities.

Seabaugh, G.O., \& Schumaker, J.B. (1981). The effects of self-regulation training on the academic productivity of $L D$ and non- $L D$ adolescents (Research report \#37). Lawrence: University of Kansas Institute of Research on Learning Disabilities.

Seager, P. (1985). Teaching sixth grade LD students LINKS: A listening/ notetaking strategy. Unpublished master's thesis, University of Kansas, Lawrence.

Smith, D.D. (1984). Effective discipline. Austin, TX: Pro-Ed.

Smith, D.D., Robinson, S., \& Voress, J. (1982). The learning disabled: The transition from dependence to independence. Topics in Learning and Learning Disabilities, 2, 27-39.

Todd, L.C., \& Curti, M. (1982) Rise of the American nation. New York: Harcourt, Brace.

Will, M. (1985). Let us pause and reflect-but not too long. Exceptional Children, 51(1) 11-16.

Wong, B.L., \& Jones, W. (1982). Increasing metacomprehension in learning disabled and normally achieving students through self-questioning training. Learning Disability Quarterly, 5, 226-240.

Ysseldyke, J. (1983). Generalizations from five years of research on assessment and decision making: The University of Minnesota Institute. Exceptional Education Quarterly, 4, 75-94. 